\title{
Kajian Analisis Sesar Di Perbukitan Jiwo Barat, Kecamatan Bayat, Kabupaten Klaten, Jawa Tengah
}

\author{
Ikhwannur Adha ${ }^{*}$, Anis Kurniasih ${ }^{2}$, Hadi Nugroho ${ }^{2}$, Prakosa Rachwibowo ${ }^{2}$ \\ ${ }^{1}$ Departemen Teknik Geologi ITB, Jl.Ganesha no. 10 Bandung \\ ${ }^{2}$ Departemen Teknik Geologi UNDIP, Jl. Prof. Soedharto Tembalang Semarang
}

\begin{abstract}
Abstrak
Bayat adalah salah satu daerah di Pulau Jawa yang memiliki singkapan batuan pra-Tersier. Batuan terkekarkan karena aktivitas tektonik. Hal ini membutuhkan penjelasan dan analisis terperinci untuk memahami zona sesar dan mekanismenya. Penelitian dilakukan untuk mengetahui zona sesar dan karakteristiknya di Perbukitan Jiwo Barat, Kecamatan Bayat, Kabupaten Klaten, Jawa Tengah, dan juga mekanisme pembentukan zona sesar untuk mengetahui kerangka tektoniknya.

Metode penelitian ini meliputi analisis topografi, analisis petrografi, proyeksi stereografi, dan penentuan kronostratigrafi. Proyeksi stereografi memanfaatkan data hasil pengukurn struktur lapangan dan dijalankan pada perangkat lunak Dips. Hasil analisis dipakai untuk mendukung interpretasi tentang mekanisme pembentukan zona sesar di daerah penelitian.

Stratigrafi di lokasi penelitian, dari urutan tua ke muda, terdiri dari Batuan Metamorf, Batupasir, Batugamping Eosen, Intrusi Batuan Beku, Batugamping Miosen, dan Aluvial. Zona sesar yang ditemukan di daerah penelitian adalah sesar mendatar menganan yang terdiri dari Sesar Mendatar Tugu, Sesar Mendatar Sari dan Sesar Mendatar Kebo, dan detachment fault yang terdiri dari Jowo Detachment Fault. Zona sesar memiliki dua orientasi utama, barat daya-timurlaut $\left(\mathrm{N} 217^{\circ} \mathrm{E}\right)$ dan barat laut-tenggara $\left(\mathrm{N} 330^{\circ}\right.$ E, N $122^{\circ}$ E, dan $\mathrm{N} 287^{\circ}$ E). Mekanisme pembentukan zona sesar di lokasi penelitian terjadi dalam dua periode tektonik, pada Kapur Akhir karena subduksi baratdaya baratlaut yang membentuk Sesar Mendatar Tugu dan Sesar Mendatar Kebo, dan pada Akhir EosenOligosen yang disebabkan oleh subduksi utara-selatan yang membentuk Sesar Mendatar Sari dan Jowo Detachment Fault.
\end{abstract}

Kata kunci : Analisis sesar, Perbukitan Jiwo Barat, proyeksi stereografi.

\begin{abstract}
Bayat is one of location in Java Island with Pre-Tertiary rocks outcrops. Rocks are jointed due to tectonic activity, thus geological structures are formed. It requires detailed explanation and analysis to understand about fault zones and its mechanism. This research is conducted to understand fault zones and its characteristics of West Jiwo Hills, Kecamatan Bayat, Kabupaten Klaten, Central Java, and also the forming mechanism of fault zones to know its tectonic setting.

The methods of this research includes topographic analysis, petrographic analysis, stereographic projection, and determining chronostratigraphic. The stereographic projection utilized field joint data that connected with fault zones characteristic, run in Dips software. The result supports the interpretation about the forming mechanism of fault zones in research area.

The stratigraphy of research location, oldest to youngest, consist of Metamorphic Rocks, Sandstone, Eocene Limestone, Igneous Rocks Intrusion, Miocene Limestone, and Alluvial. The fault zones found on research area are dextral fault consist of Mendatar Tugu Fault, Mendatar Sari Fault and Mendatar Kebo Fault, and detachment fault consist of Jowo Detachment Fault. The fault zones has two major orientations, southwest-northeast $\left(N 217^{\circ} \mathrm{E}\right)$ and northwest-southeast $\left(N 330^{\circ}\right.$ $E, N 122^{\circ} \mathrm{E}$, and $N 287^{\circ} \mathrm{E}$ ). The forming mechanism of fault zones in research location occurred in two tectonic periods, at Late Cretaceous due to southwest-northeast subduction that formed Mendatar Tugu Fault and Mendatar Kebo Fault, and at Late Eocene-Oligocene caused by northsouth subduction that formed Mendatar Sari Fault and Jowo Detachment Fault.
\end{abstract}

Keywords : Fault Analysis, West Jiwo Hills, Stereographic Projection.

*) Korespondensi : ikhwannur.adha@gmail.com 
PENDAHULUAN

Singkapan batuan yang ditemukan di Kompleks Bayat terdiri dari jenis Batuan Beku, Sedimen, dan Metamorf, yang berumur Pra-Tersier hingga Neogen. Kelompok batuan Pra-Tersier yang tersingkap di Bayat sebagian besar terdiri dari satuan batuan yang terkekarkan akibat suatu gejala penggerusan tektonik yang kuat. Dengan demikian struktur geologi yang beragam dapat dijumpai di daerah tersebut.

Namun, kenyataan di lapangan sukar untuk menemukan struktur geologi tersebut, terutama berupa sesar. Hal ini diakibatkan karena batuan yang tersingkap sebagian besar terkekarkan secara intensif sehingga zona sesar tidak dapat ditentukan secara langsung. Selain itu pembahasan mengenai hal ini masih bersifat regional dan belum semuanya terpetakan, sehingga fenomena ini menarik untuk dipelajari dengan kajian yang lebih mendalam.

Kajian penelitian ini meliputi penentuan zona sesar, jenis sesar, dan karakteristiknya di Perbukitan Jiwo Barat, Kecamatan Bayat, Kabupaten Klaten, Jawa Tengah, serta penentuan arah gaya dan mekanisme pembentukan zona sesar untuk mengetahui tatanan tektonik daerah penelitian. Hal-hal yang menjadi tujuan dari penelitian ini yaitu menentukan pelamparan zona sesar, jenis sesar, dan karakteristiknya pada daerah penelitian, serta menentukan gaya pembentuk zona sesar yang terdapat pada daerah penelitian dan hubungannya dengan tatanan tektonik daerah penelitian.

\section{Sesar}

Sesar atau patahan (fault) menurut Ragan (1973) merupakan bidang atau zona rekahan yang terlihat telah mengalami pergerakan. Berdasarkan Asikin (1979), sesar adalah suatu rekahan pada batuan yang telah mengalami pergeseran sehingga terjadi perpindahan antara bagian yang berhadapan, dengan arah yang sejajar dengan bidang patahan. Pergeseran terjadi karena adanya gaya tektonik yang bekerja di dalam bumi.
Anderson (1951 dalam McClay, 1987) dan Ragan (1973) mengenali sifat dari arah tegasan utama, dalam hubungannya dengan hukum Coulomb mengenai batas kekuatan suatu massa yang menyiratkan bahwa sesar naik, mendatar dan normal terbentuk pada atau dekat permukaan bumi, yang terdapat 3 arah tegasan dengan 2 arah tegasan horizontal dan 1 arah tegasan vertikal.

Secara genesis, pergerakan relatif sepanjang sesar, dibedakan menjadi lima jenis sesar yaitu :

1. Sesar naik (thrust fault) adalah sesar yang blok di atas bidang sesar bergerak relatif naik terhadap blok yang berada di bawah bidang sesar, dengan sudut kemiringan bidang sesar kurang dari $30^{\circ}$ (Hardwood, 2009).

2. Sesar berbalik (reverse fault) adalah sesar yang blok di atas bidang sesar bergerak relatif naik terhadap blok yang berada di bawah bidang sesar, dengan sudut kemiringan bidang sesar antara $30^{\circ}$ hingga $90^{\circ}$ (Hardwood, 2009).

3. Sesar turun (gravity atau normal fault) adalah sesar yang blok di atas bidang sesar bergerak relatif turun terhadap blok yang berada di bawah bidang sesar, dengan sudut kemiringan bidang sesar antara $30^{\circ}$ hingga $90^{\circ}$ (Hardwood, 2009).

4. Detachment fault adalah sesar yang blok di atas bidang sesar bergerak relatif turun terhadap blok yang berada di bawah bidang sesar, dengan sudut kemiringan bidang sesar kurang dari $30^{\circ}$ (Hardwood, 2009).

5. Sesar mendatar (strike-slip fault) adalah sesar yang pergerakannya sejajar terhadap arah jurus bidangnya.

\section{Analisis Sesar}

Menurut Bott (1959), pergerakan sesar akan mengikuti arah kekar gerus yang berpasangan (Conjugate Shear). Dalam analisis sesar dengan menggunakan data kekar untuk menetukan jenis sesar dapat diterapkan dengan menggunakan konsep klasifikasi sesar secara dinamik menurut Anderson dengan patokan sebagai berikut : 
1. Tegasan utama maksimum $\left(\sigma_{1}\right)$ berada pada titik tengah perpotongan 2 bidang kekar gerus berpotongan yang mempunyai sudut sempit $\left(0^{\circ}-90^{\circ}\right)$.

2. Tegasan utama menengah $\left(\sigma_{2}\right)$ berada pada titik perpotongan antara 2 bidang kekar gerus berpotongan.

3. Tegasan utama minimum $\left(\sigma_{3}\right)$ berada pada titik tengah perpotongan 2 bidang kekar gerus berpotongan yang mempunyai sudut tumpul $\left(90^{\circ}-180^{\circ}\right)$.

4. Ketiga tegasan utama saling tegak lurus.

\section{Geologi Regional Daerah Penelitian}

Secara fisiografis Perbukitan Bayat tersusun dari batuan Pra-Tersier dan Tersier yang berada di sekitar endapan Kuarter, yang terutama terdiri dari endapan flufio-vulkanik Merapi. Elevasi tertinggi dari puncak-puncak yang ada tidak lebih dari 400 meter diatas muka laut, sehingga perbukitan tersebut dapat disebut perbukitan rendah.

Raharjo (1997) menyatakan bahwa batuan tertua yang tersingkap di daerah Perbukitan Jiwo adalah komplek batuan metamorf yang diduga berumur PraTersier. Komplek Batuan ini merupakan basement dari cekungan sedimen Paleogen. Endapan Paleogen yang dijumpai berupa batupasir dengan sisipan batugamping yang kaya foraminifera besar. Batuan tersebut diterobos oleh tubuh batuan beku yang terutama terdiri dari mikrodiorit. Penerobosan ini diduga terjadi pada Paleogen akhir. Menumpang secara tidak selaras di atas batuan beku dan batuan sedimen Paleogen tersebut terdapat batuan karbonat berumur Neogen yang dijumpai dalam bentuk dua fasies yang berbeda, yaitu fasies laut dalam dan fasies laut dangkal. Erosi yang terjadi pada Neogen atas berakibat pada pengendapan batuan Kuarter yang tidak selaras di atas batuan yang lebih tua. Batuan yang terendapkan pada Kuarter adalah breksi vulkanik, endapan koluvial, endapan fluvio-vulkanik dan endapan aluvial.

Dari segi struktur geologi, daerah Bayat termasuk Zona Pegunungan Selatan Jawa
Tengah dan merupakan daerah dengan struktur lipatan yang terdiri dari struktur lipatan pada batuan Eosen dan pada batuan yang lebih muda. Batuan Paleogen dan Neogen di daerah ini terlipatkan dan membentuk antiklin Cakaran yang berintikan batuan Formasi WungkalGamping Eosen dan struktur homoklin berupa perlapisan batuan yang lebih muda dengan kemiringan umum ke selatan. Arah struktur sesar di daerah Perbukitan Jiwo menunjukkan arah umum yang dapat dikelompokkan menjadi empat; arah timurlaut - baratdaya, utara - selatan, baratlaut - tenggara, dan timur - barat (Prasetyadi, 2007).

\section{METODOLOGI}

Penelitian ini secara umum didasarkan pada evaluasi data lapangan. Observasi lapangan dilakukan untuk mengetahui kondisi geologi yang meliputi litologi, struktur geologi, dan penentuan umur relatif batuan. Selanjutnya dilakukan analisis topografi untuk mengenali kondisi daerah penelitian dan asumsi mengenai zona sesar. Analisis petrografi dilakukan untuk mengetahui jenis dan nama batuan berdasarkan tekstur, struktur dan komposisi mineral batuan.

\section{Analisis Sesar}

Analisis sesar pada daerah penelitian dilakukan melalui tiga tahapan. Tahap pertama adalah melalui pendekatan tidak langsung dengan cara menarik pola-pola kelurusan pada peta topografi. Tahap kedua melalui pengamatan secara langsung di lapangan dan pengambilan data lapangan berupa arah dan kedudukan kekar gerus, kemenerusan intrusi, orientasi urat mineral, zona hancuran yang tersusun oleh kekar gerus yang sangat intensif, dan keberadaan mataair. Tahap ketiga melalui analisis lanjut terhadap data lapangan dengan proyeksi stereografis untuk mengetahui mekanisme sesar yang terjadi di daerah penelitian. Proyeksi stereografis dibuat dari data kekar dengan perangkat lunak Dips yang ditampilkan dalam 
diagram kontur pada stereonet yang menunjukkan penyebaran dari kekar gerus. Selanjutnya, ditentukan maxima yang diambil dari puncak kontur yang memiliki kerapatan yang tinggi. Maxima tersebut merupakan arah dan kedudukan kekar gerus dominan yang terbentuk. Analisis dilakukan dari data STA yang mewakili zona sesar, yaitu STA 20, 22, 23, 25, 27, $28,29,30,31,32,33,34,35,37,38,51$,
52, dan 54 (seperti yang terlihat pada Gambar 2). Data kekar yang diukur setiap STA sebanyak sekitar 30 buah kekar. Pengukuran kekar gerus pada setiap STA dikelompokkan kembali sehingga menjadi zona-zona yang dapat mewakili zona sesar. Penentuan tegasan utama mengguna-kan konsep klasifikasi sesar secara dinamik menurut Anderson (1951); dalam Bott (1959).
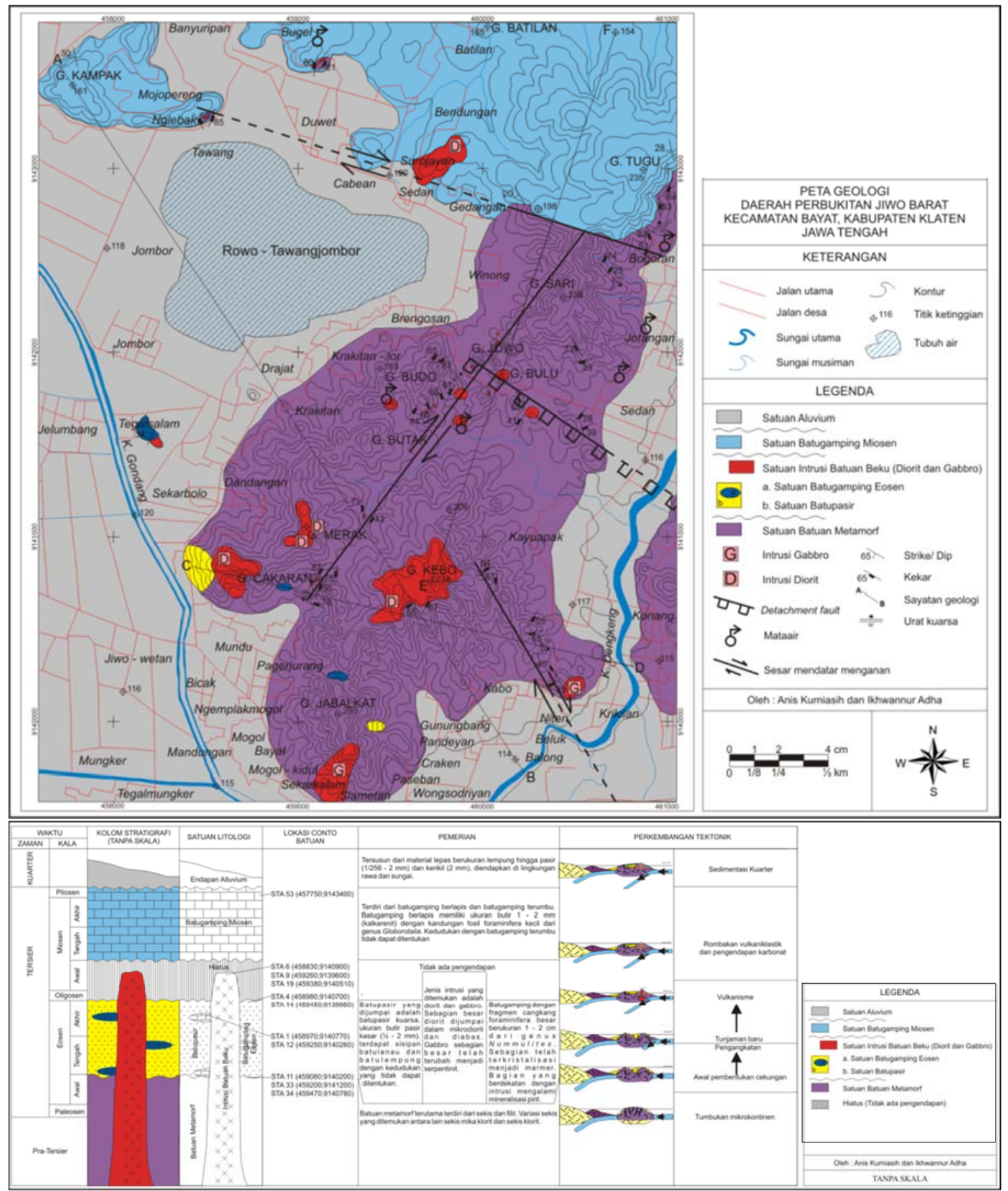

Gambar 1. Peta geologi dan kolom stratigrafi daerah penelitian. 
HASIL

\section{Stratigrafi Daerah Penelitian}

Lokasi penelitian merupakan daerah ditemukannya batuan Pra-Tersier di antara batuan Neogen, penyebaran dan urutannya ditunjukkan pada Gambar 1. Urutan stratigrafi dari batuan tua ke muda yaitu Satuan Batuan Metamorf, Batupasir, Batugamping Eosen, Satuan Intrusi Batuan Beku, Batugamping Miosen, dan Endapan Alluvium.

\section{Struktur Geologi Daerah Penelitian}

Struktur yang berkembang pada daerah penelitian terdiri dari detachment fault, dan sesar mendatar menganan (Gambar 2). Satuan batuan yang terpotong oleh struktur geologi tersebut adalah Satuan Batuan Metamorf yang ditunjukkan dengan adanya kekar gerus yang intensif dan kelurusan intrusi di beberapa tempat, sedangkan pada Satuan Batugamping Miosen tidak dijumpai tanda-tanda yang menunjukkan satuan ini terlibat dalam struktur geologi ini, seperti tidak dijumpai kekar gerus yang memotong satuan ini dan tidak dijumpai baking effect pada kontak antara Satuan Batugamping Miosen dengan Satuan Intrusi Batuan Beku yang terdapat di G. Tugu.

Lapisan breksi sesar juga dijumpai sebagai kontak antara Satuan Batuan Metamorf dan Satuan Batugamping Miosen yang ditandai dengan tidak dijumpai matriks batugamping pada lapisan breksi tersebut. Struktur geologi tersebut mulai terbentuk saat atau pasca pembentukan Satuan Batuan Metamorf dan sebelum pengendapan Satuan Batugamping Miosen.

Bidang sesar yang tegas pada daerah penelitian tidak dapat dijumpai bidang sesarnya karena kondisi singkapan yang sudah lapuk dan kekar gerus yang intensif. Sesar tersebut diindikasikan melalui bentukan topografi berupa pola kelurusan punggungan, perbukitan dan lembah, pembelokan sungai secara tiba-tiba, kekar gerus, zona hancuran yang tersusun oleh kekar gerus yang sangat intensif, kelurusan intrusi, dan adanya urat kuarsa serta mataair. Selain itu, dilakukan pula analisis sesar dengan proyeksi stereografis sehingga dapat diketahui jenis dari sesar yang terdapat di daerah penelitian.

\section{Interpretasi Zona Sesar}

Penarikan pola kelurusan punggungan, perbukitan, dan lembah di daerah penelitian yang dilakukan pada peta topografi diperoleh dua arah umum kelurusan yaitu arah baratdaya-timurlaut dan arah baratlauttenggara (Gambar 2). Pola kelurusan ini menjadi patokan dalam pengamatan lapangan untuk memperoleh data lapangan mengenai struktur geologi sehingga diperoleh data yang akurat dan mewakili zona sesar.

Penamaan sesar pada daerah penelitian ditentukan berdasarkan letak geografis yang dilalui oleh zona sesar tersebut. Daerah penelitian memiliki empat zona sesar yaitu Sesar Mendatar Tugu, Sesar Mendatar Kebo, Jowo Detachment Fault, dan Sesar Mendatar Sari (Gambar 2).

\section{Sesar Mendatar Tugu}

Sesar ini melampar dari G. Tugu hingga G. Kampak dan memiliki pergerakan relatif menganan, ditunjukkan dengan morfologi G. Tugu yang bergerak relatif menganan.

Pada zona sesar ini dijumpai intrusi, urat kuarsa, dan mataair. Intrusi dijumpai di sekitar Nglebak, Bugel, Surojayan, dan Sedan. Urat yang terbentuk memiliki kedudukan umum sekitar $\mathrm{N} 240^{\circ} \mathrm{E} / 70^{\circ}$, sedangkan mataair dapat dijumpai di Bogoran dan Bugel.

Analisis sesar dilakukan pada dua bagian, yaitu di bagian barat dengan data kekar gerus dari STA 51-52 dan di bagian timur dengan data kekar gerus dari STA 3031.

Hasil analisis sesar dengan proyeksi stereografis menunjukkan bahwa arah tegasan utama maksimum sebagai arah gaya pembentuk sesar ini relatif berarah baratdaya-timurlaut $\left(\mathrm{N} 13^{\circ} \mathrm{E}\right)$ (Gambar 3 dan Gambar 4). Tegasan utama menengah memiliki kedudukan relatif vertikal. 


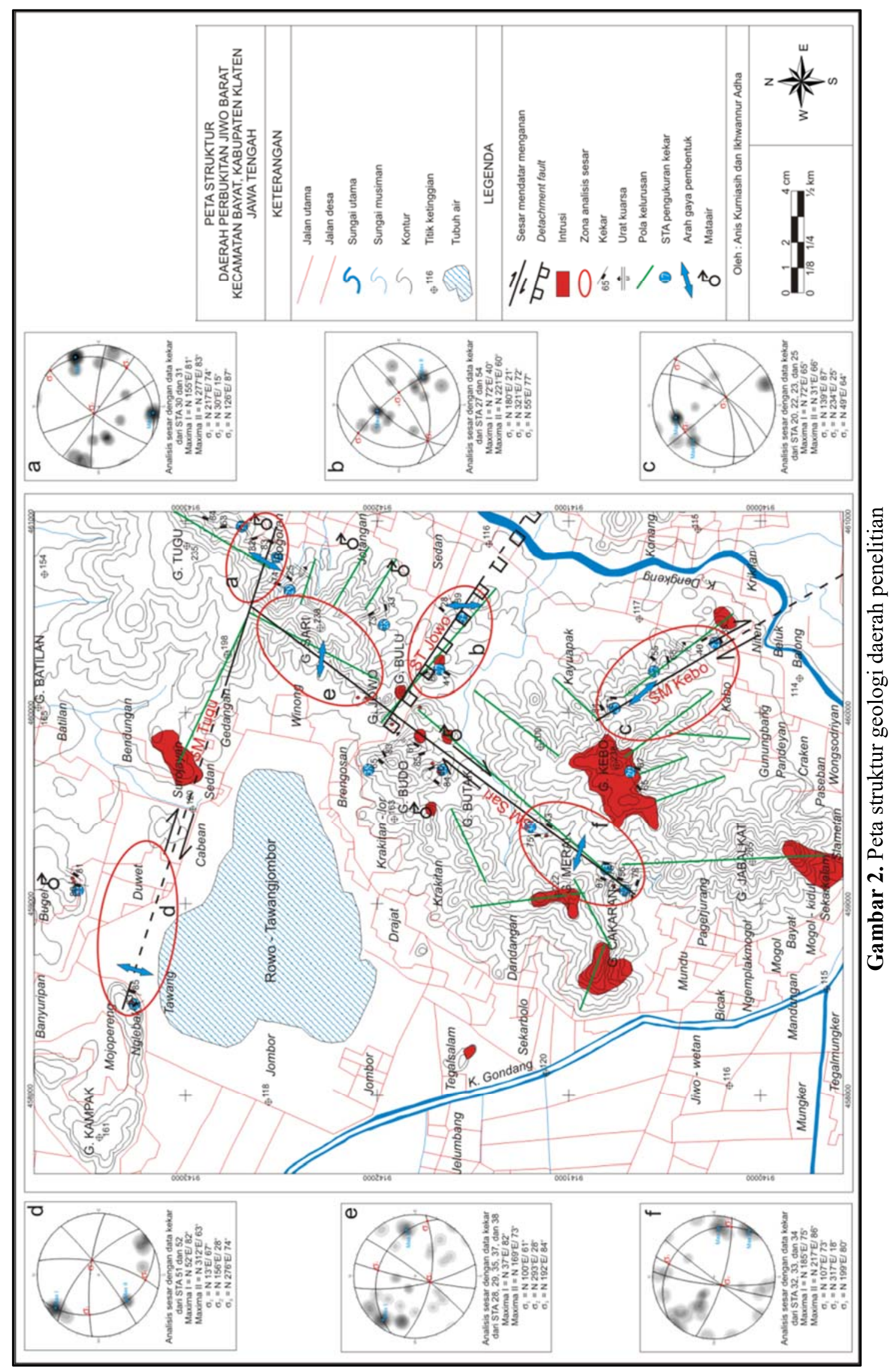




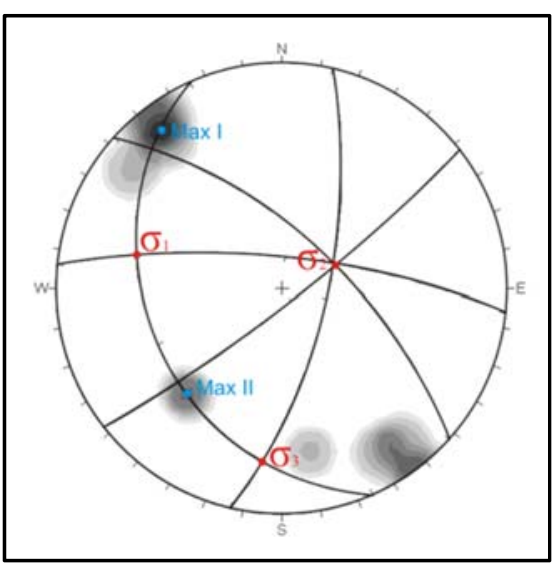

Gambar 3. Hasil analisis sesar SM Tugu pada bagian barat $\left(\sigma_{1}=\mathrm{N} 13^{\circ} \mathrm{E} / 67^{\circ}, \sigma_{2}=\mathrm{N} 156^{\circ} \mathrm{E} /\right.$ $\left.28^{\circ}, \sigma_{3}=\mathrm{N} 276^{\circ} \mathrm{E} / 74^{\circ}\right)$.

Mengacu kepada Anderson (1951 dalam McClay, 1987), sesar ini diklasifikasikan sebagai sesar mendatar (SM).

Kedudukan bidang sesar berdasarkan analisis sesar yang diperoleh adalah $\mathrm{N} 287^{\circ} \mathrm{E} / 8^{\circ}$. Berdasarkan arah gaya pembentuk sesar ini, dapat diinterpretasikan bahwa sesar ini terbentuk akibat peristiwa tektonik yang searah dengan Meratus pada Zaman Kapur Akhir.

\section{Sesar Mendatar Kebo}

Analisis sesar dilakukan dengan data kekar gerus dari STA 20, 22, 23, dan 25. Sesar mendatar ini melampar dari G. Kebo ke arah tenggara hingga Kali Dengkeng. Sesar ini memiliki pergerakan relatif menganan, terlihat dari pembelokan sungai pada Kali Dengkeng (Gambar 2).

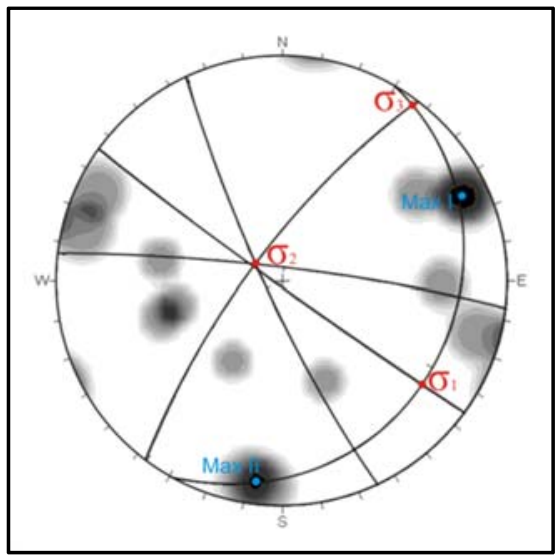

Gambar 4. Hasil analisis sesar SM Tugu pada bagian timur $\left(\sigma_{1}=\mathrm{N} 217^{\circ} \mathrm{E} / 74^{\circ}, \sigma_{2}=\mathrm{N} 30^{\circ} \mathrm{E} /\right.$ $\left.15^{\circ}, \sigma_{3}=\mathrm{N} 126^{\circ} \mathrm{E} / 87^{\circ}\right)$.
Proyeksi stereografi menunjukkan bahwa arah tegasan utama maksimum sebagai arah gaya pembentuk sesar ini relatif berarah baratlaut-tenggara $\left(\mathrm{N} 139^{\circ} \mathrm{E}\right)$ sejajar dengan arah pelamparan sesar ini. Seharusnya arah gaya pembentuk berpotongan atau tegak lurus terhadap arah pelamparannya, tetapi dapat terjadi karena proses pengangkatan intrusi pada zonasesar ini yang menyebabkan arah dan kedudukan kekar gerus yang tersingkap sekarang telah mengalami perubahan.

Tegasan utama menengah memiliki kedudukan relatif vertikal (Gambar 4) yang menurut Anderson (1951 dalam McClay, 1987) diklasifikasikan sebagai sesar mendatar. Kedudukan bidang sesar berdasarkan analisis sesar yang diperoleh adalah $\mathrm{N} 330^{\circ} \mathrm{E} / 86^{\circ}$. Berdasarkan arah pelamparan sesar ini, sesar ini terbentuk akibat tektonik yang searah dengan Meratus pada Zaman Kapur Akhir.

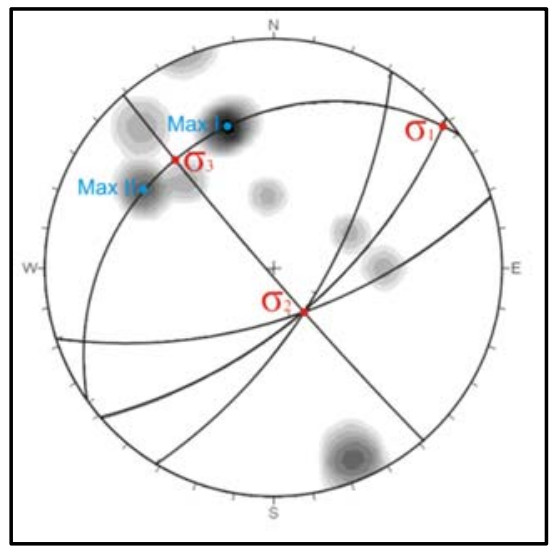

Gambar 5. Hasil analisis sesar pada SM Kebo $\left(\sigma_{1}=\mathrm{N} 139^{\circ} \mathrm{E} / 87^{\circ}, \sigma_{2}=\mathrm{N} 234^{\circ} \mathrm{E} / 25^{\circ}, \sigma_{3}=\mathrm{N}\right.$ $\left.49^{\circ} \mathrm{E} / 64^{\circ}\right)$.

\section{Jowo Detachment Fault}

Melampar dari G. Jowo, melewati G. Bulu hingga Kali Dengkeng, zona sesar ini berpotongan dengan SM Sari sehingga memberi jalan keluar intrusi magmatik pada daerah ini.

Analisis sesar yang dilakukan dengan data kekar gerus dari STA 27 dan 54. Proyeksi stereografis menunjukkan bahwa tegasan utama maksimum relatif berarah utara-selatan $\left(\mathrm{N} 180^{\circ}\right.$ E) (Gambar 6), dan tegasan utama maksimum memiliki 
kedudukan relatif vertikal yang menurut Anderson (1951 dalam McClay, 1987) diklasifikasikan sebagai detachment fault (DF).

Kedudukan bidang sesar berdasarkan analisis sesar yang diperoleh adalah $\mathrm{N} 122^{\circ} \mathrm{E} / 16^{\circ}$. Dengan demikian, dapat diinterpretasikan bahwa sesar ini terbentuk akibat peristiwa tektonik berarah Pulau Jawa pada Zaman Eosen Akhir-Oligosen.

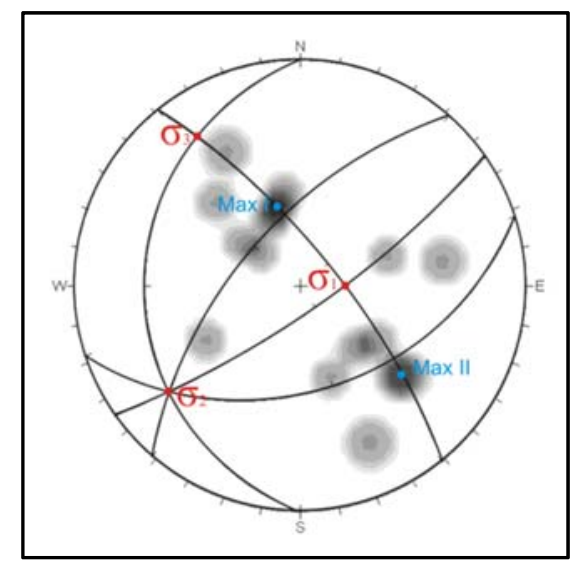

Gambar 6. Hasil analisis sesar pada Jowo DF $\left(\sigma_{1}=\mathrm{N} 180^{\circ} \mathrm{E} / 21^{\circ}, \sigma_{2}=\mathrm{N} 321^{\circ} \mathrm{E} / 72^{\circ}, \sigma_{3}=\mathrm{N}\right.$ $\left.55^{\circ} \mathrm{E} / 77^{\circ}\right)$.

\section{Sesar Mendatar Sari}

Sesar ini melampar dari G. Sari hingga lembah antara G. Cakaran hingga G. Merak dengan G. Kebo. Sesar ini memiliki pergerakan relatif menganan terlihat dari morfologi topografi pada G. Kebo yang bergerak relatif menganan terhadap perbukitan di sebelah barat zona sesar.

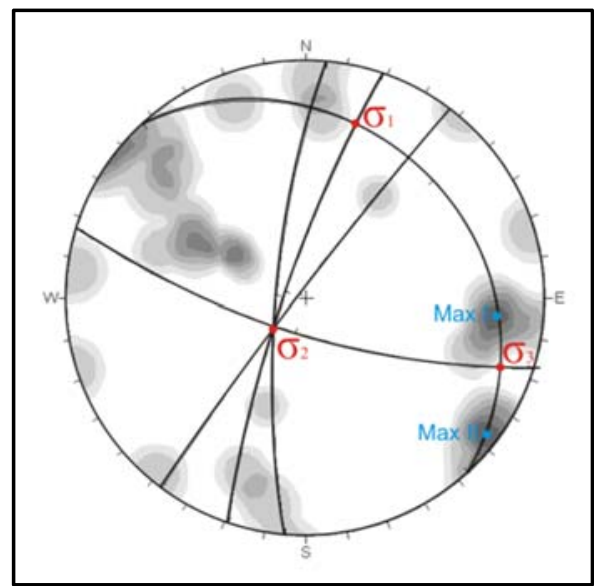

Gambar 7. Hasil analisis sesar SM Sari pada bagian selatan $\left(\sigma_{1}=\mathrm{N} 107^{\circ} \mathrm{E} / 73^{\circ}, \sigma_{2}=\mathrm{N}\right.$ $\left.317^{\circ} \mathrm{E} / 18^{\circ}, \sigma_{3}=\mathrm{N} 199^{\circ} \mathrm{E} / 80^{\circ}\right)$.
Pada zona ini dijumpai intrusi, terutama di sepanjang lembah antara G. Cakaran-G. Merak dengan G. Kebo dan sekitar G. Jowo serta G. Sari karena merupakan daerah perpotongan dengan Jowo DF. Sejumlah urat kuarsa dan mataair juga terbentuk pada zona Jowo DF.

Urat yang terisi kuarsa di sepanjang lembah antara G. Cakaran-G. Merak dengan G. Kebo secara umum memiliki kedudukan $\mathrm{N} 120^{\circ} \mathrm{E} / 50^{\circ}$, sedangkan di sekitar G. Jowo memiliki kedudukan umum $\mathrm{N} 300^{\circ} \mathrm{E} / 80^{\circ}$. Analisis sesar yang dilakukan terdiri dari dua bagian, yaitu: bagian selatan (data kekar gerus dari STA 32, 33 dan 34) dan bagian utara dengan (data kekar gerus dari STA 28, 29, 35, 37, dan 38).

Hasil analisis sesar dengan proyeksi stereografis menunjukkan arah tegasan utama maksimum sesar ini relatif berarah baratlaut-tenggara ( $\mathrm{N} \mathrm{107^{ \circ }}$ E) (Gambar 7 dan Gambar 8), dan tegasan utama menengah memiliki kedudukan relatif vertikal sehingga menurut Anderson (1951 dalam McClay, 1987) diklasifikasikan sebagai sesar mendatar.

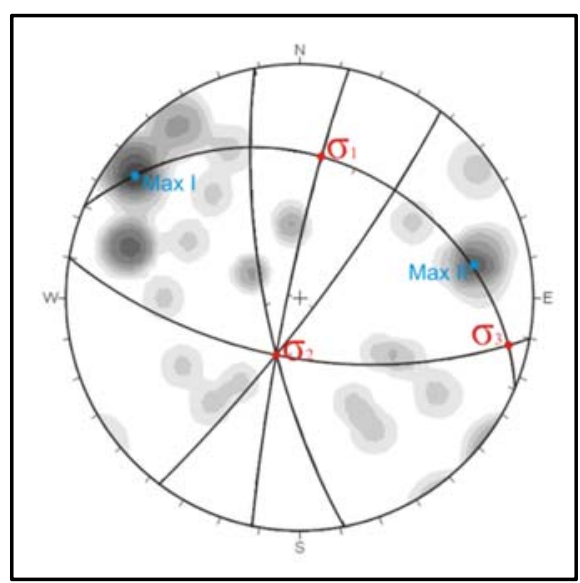

Gambar 8. Hasil analisis sesar SM Sari pada bagian utara $\left(\sigma_{1}=\mathrm{N} 100^{\circ} \mathrm{E} / 61^{\circ}, \sigma_{2}=\mathrm{N} 293^{\circ} \mathrm{E} /\right.$ $\left.28^{\circ}, \sigma_{3}=\mathrm{N} 192^{\circ} \mathrm{E} / 84^{\circ}\right)$.

Kedudukan bidang sesar berdasarkan analisis sesar yang diperoleh adalah $\mathrm{N} 217^{\circ} \mathrm{E} / 8^{\circ}$. Berdasarkan arah gaya pembentuk sesar dan pelamparannya, dapat diinterpretasikan bahwa sesar ini terbentuk 
akibat peristiwa tektonik berarah Pulau Jawa pada Zaman Eosen Akhir-Oligosen.

\section{PEMBAHASAN}

\section{Sejarah Geologi dan Tektonostratigrafi}

Batuan metamorf adalah batuan tertua di daerah penelitian dan merupakan batuan dasar dari jenis batuan lain di sekitarnya. Interpretasi hasil analisis karakteristik batuan metamorf menunjukkan bahwa batuan metamorf terbentuk oleh proses metamorfisme regional akibat proses orogenesis yang berlangsung lambat pada daerah yang luas.

Sementara itu, himpunan batuan di daerah penelitian didominasi oleh batuan metamorf derajat rendah, seperti sekis dan filit, sehingga himpunan batuan di daerah penelitian diinterpretasikan sebagai kompleks konvergen yang lebih berciri asal kontinen. Interpretasi ini didukung penelitian terdahulu yang dilakukan oleh Prasetyadi (2007), yang mengungkap adanya mikrokontinen Jawa Timur yang menumbuk lempeng benua Eurasia pada Kapur Akhir dan mengakibatkan proses subduksi Karangsambung berhenti atau tidak aktif. Sedangkan daerah penelitian terletak pada mikrokontinen tersebut, sehingga kemungkinan besar batuan metamorf di daerah penelitian terbentuk akibat tumbukan mikrokontinen dengan lempeng benua Eurasia (Gambar 9a). Selain itu, gaya tektonik yang berarah baratdaya-timurlaut searah dengan arah subduksi Meratus mengakibatkan terbentuknya SM Tugu dan SM Kebo.

Berdasarkan kandungan mineral pada sekis, diperkirakan batuan ini telah mengalami retrograde metamorphisme, ditandai dengan kehadiran mineral muskovit dan klorit hasil dari rekristalisasi biotit, dan plagioklas. Hal ini menunjukkan penurunan temperatur dari kisaran $425^{\circ} \mathrm{C}$ $-450^{\circ} \mathrm{C}$ menjadi $305^{\circ} \mathrm{C}-375^{\circ} \mathrm{C}$, dan penurunan tekanan dari kisaran $0,4-7,7$
KBar atau setara dengan $0,4 \times 10^{8} \mathrm{~kg} / \mathrm{ms}^{2}-$ $7,7 \times 10^{8} \mathrm{~kg} / \mathrm{ms}^{2}$ menjadi $0,4-5 \mathrm{KBar}$ atau setara dengan $0,4 \times 10^{8} \mathrm{~kg} / \mathrm{ms}^{2}-5 \times 10^{8}$ $\mathrm{kg} / \mathrm{ms}^{2}$.

Proses metamorfisme retrogradasi diinterpretasikan sebagai akibat aktivitas pengangkatan sangat lambat, yang membentuk batuan metamorf pada fase sebelumnya. Setelah pengangkatan, batuan tersingkap di permukaan dan mengalami proses eksogenik berupa pelapukan dan erosi. Proses ini diperkirakan terjadi pada Eosen Awal (Gambar 9b). Pada Eosen Tengah (Gambar 9c), diperkirakan kembali terjadi penurunan permukaan oleh patahan sehingga daerah ini kembali mengalami genang laut dan terendapkan batuan sedimen Eosen yakni satuan batupasir dan batugamping (Formasi Wungkal Gamping Eosen).

Setelah itu, pada Eosen Akhir hingga Oligesin Awal (Gambar 9d) mulai terjadi perubahan arah subduksi menjadi berarah utara-selatan yang mengakibatkan pengangkatan kembali serta terbentuknya SM Sari dan Jowo DF pada daerah penelitian. Sementara itu proses subduksi terus berlangsung dan membentuk busur gunung api (Old Andesite Formation) pada Oligosen Tengah (Gambar 9e) dan banyak terjadi intrusi. Pada Oligosen Tengah hingga Miosen Awal banyak terjadi proses tektonik yang ditandai dengan pengangkatan dan genang laut berturut turut membentuk stratigrafi Pegunungan Selatan.

Pada Miosen Tengah (Gambar 9f), kembali terjadi genang laut sehingga terbentuk batugamping dengan ciri pengendapan laut dangkal. Setelah itu kembali terjadi pengangkatan sehingga batuan yang lebih tua mengalami erosi. Selanjutnya terendapkan secara tidak selaras endapan aluvium sebagai satuan yang paling muda. 


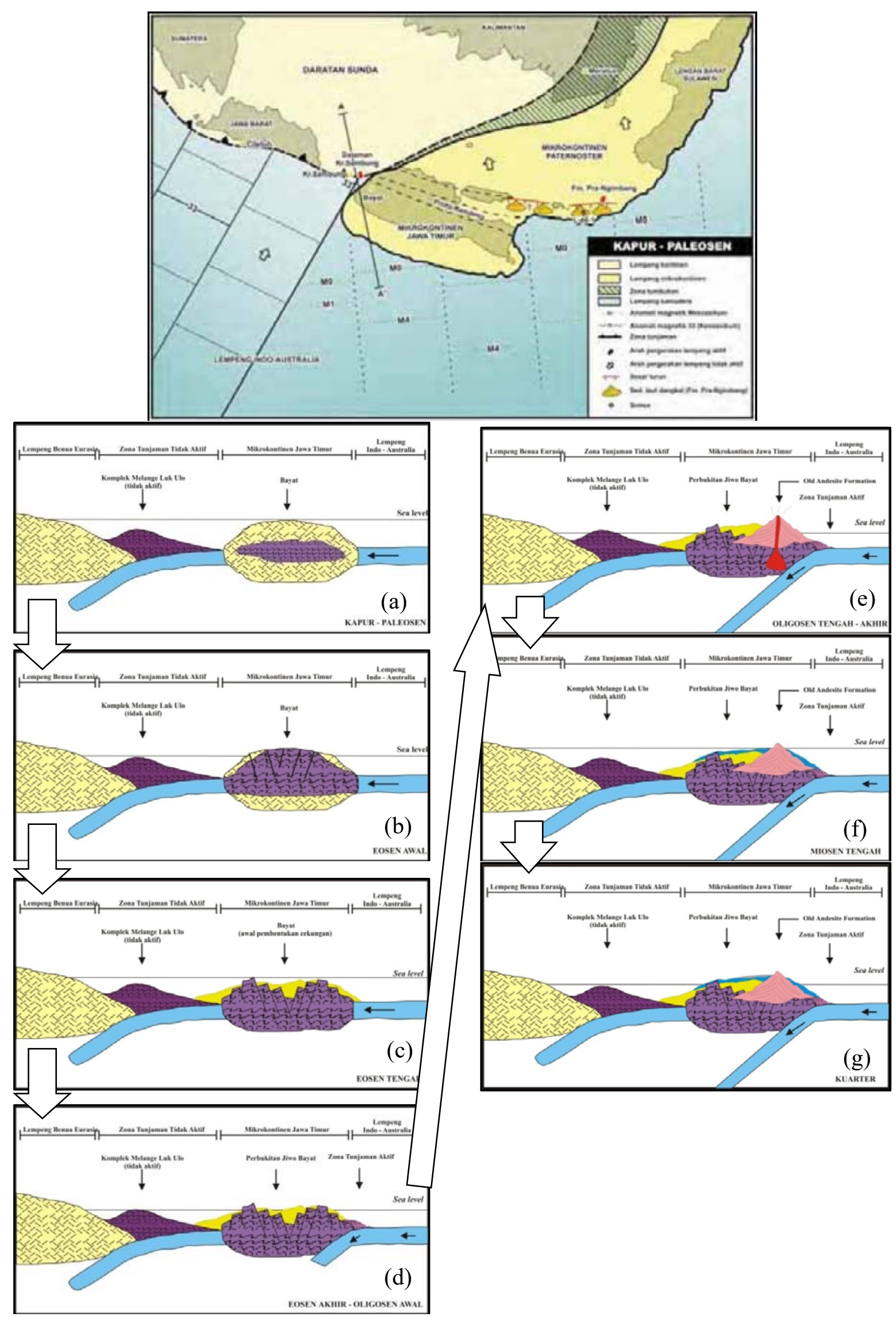

Gambar 9. Ilustrasi perkembangan tektonik dari Kapur hingga Holosen (Prasetyadi, 2007 dengan modifikasi, tanpa skala). 


\section{KESIMPULAN}

Daerah penelitian zona sesar dengan dua arah utama yaitu arah baratdaya-timurlaut $\left(\mathrm{N} 217^{\circ} \mathrm{E}\right)$ dan baratlaut-tenggara $\left(\mathrm{N} 330^{\circ} \mathrm{E}\right.$, $\mathrm{N} 122^{\circ} \mathrm{E}$, dan $\mathrm{N} 287^{\circ} \mathrm{E}$ ). Zona tersebut meliputi : sesar mendatar menganan yang terdiri dari Sesar Mendatar Tugu, Sesar Mendatar Sari, Sesar Mendatar Kebo, dan detachment fault berupa Jowo Detachment Fault, dengan karakteristik seperti yang terlihat pada Tabel 1 .

Tabel 1. Karakteristik zona sesar di daerah penelitian

\begin{tabular}{|c|c|c|c|c|c|c|c|c|c|}
\hline \multirow[b]{2}{*}{ Sesar } & \multirow[b]{2}{*}{$\begin{array}{c}\text { Kedudukan } \\
\text { Bidang } \\
\text { Sesar }\end{array}$} & \multicolumn{7}{|c|}{ Karakteristik Lapangan } & \multirow[b]{2}{*}{$\begin{array}{c}\text { Arah Tegasan } \\
\text { Maksimum }\end{array}$} \\
\hline & & 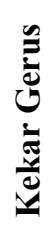 & 节 & $\stackrel{\bar{a}}{\underline{E}}$ & $\frac{\vec{\pi}}{5}$ & 离 & 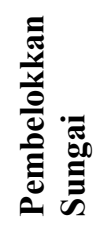 & 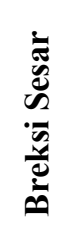 & \\
\hline $\begin{array}{c}\text { Sesar } \\
\text { Mendatar Tugu } \\
\text { (Dextral) }\end{array}$ & $\mathrm{N} 287^{0} \mathrm{E} / 86^{\circ}$ & $\sqrt{ }$ & $\sqrt{ }$ & $\sqrt{ }$ & $\sqrt{ }$ & $\sqrt{ }$ & & $\sqrt{ }$ & $\downarrow_{\mathrm{N} 13^{0} \mathrm{E}}$ \\
\hline $\begin{array}{c}\text { Sesar } \\
\text { Mendatar } \\
\text { Kebo (Dextral) }\end{array}$ & $\mathrm{N} 330^{\circ} \mathrm{E} / 86^{\circ}$ & $\sqrt{ }$ & $\sqrt{ }$ & $\sqrt{ }$ & $\sqrt{ }$ & & $\sqrt{ }$ & & $\mathrm{N} 139^{\circ} \mathrm{E}$ \\
\hline $\begin{array}{l}\text { Jowo } \\
\text { Detachment } \\
\text { Fault }\end{array}$ & $\mathrm{N} 122^{0} \mathrm{E} / 16^{\circ}$ & $\sqrt{ }$ & $\sqrt{ }$ & $\sqrt{ }$ & & & & & $\underset{\mathrm{N} 180^{\circ} \mathrm{E}}{\downarrow}$ \\
\hline $\begin{array}{c}\text { Sesar } \\
\text { Mendatar Sari } \\
(\text { Dextral })\end{array}$ & $\mathrm{N} 217^{0} \mathrm{E} / 86^{\circ}$ & $\sqrt{ }$ & $\sqrt{ }$ & $\sqrt{ }$ & $\sqrt{ }$ & $\sqrt{ }$ & & & $\underset{\mathrm{N} 107^{0} \mathrm{E}}{\longrightarrow}$ \\
\hline
\end{tabular}

\section{UCAPAN TERIMA KASIH}

Penulis bermaksud mengucapkan terima kasih kepada Bapak Tri Winarno dan semua pihak yang membantu selama pengambilan data di lapangan.

\section{DAFTAR PUSTAKA}

Asikin, Sukendar, 1979. Dasar - Dasar Geologi Struktur, Departemen Teknik Geologi ITB, Bandung.

Bott, M.H.P., 1959. The mechanisms of oblique slip faulting, Geology Magazine, Volume 96.

Hardwood, Richard, 2009. "Structural Geology", http://facweb.bhc.edu, 6 Maret 2010.

McClay, K. R., 1987. The Mapping of Geological Structures, Open University Press, New York

Prasetyadi, C., 2007. Evolusi Tektonik Paleogen Jawa Bagian Timur, Tidak dipublikasikan, Disertasi, Dept. Teknik Geologi ITB, Bandung.

Ragan, Donal M., 1973. Structural Geology: An Introduction to Geometrical Techniques, Edisi Kedua, John Wiley and Sons, New York

Rahardjo, W., 1997, "Geologi Daerah Jiwo Kecamatan Bayat", http://klastik.wordpress.com, 3 Mei 2009. 